\title{
Hamsa
}

Journal of Judaic and Islamic Studies

$4 \mid 2018$

Varia

\section{Conversions in the kingdoms of Castile, Aragon and Valencia: A point of cohabitation}

\section{Nathan Robert Dodgens}

\section{(2) OpenEdition \\ 1 Journals}

\section{Electronic version}

URL: https://journals.openedition.org/hamsa/528

DOI: 10.4000/hamsa.528

ISSN: 2183-2633

\section{Publisher}

CIDEHUS - Centro Interdisciplinar de História Culturas e Sociedades da Universidade de Évora

\section{Electronic reference}

Nathan Robert Dodgens, "Conversions in the kingdoms of Castile, Aragon and Valencia: A point of cohabitation", Hamsa [Online], 4 | 2018, Online since 31 March 2018, connection on 21 September 2021. URL: http://journals.openedition.org/hamsa/528 ; DOI: https://doi.org/10.4000/hamsa.528

\section{(ब) $\oplus \Theta$}

Hamsa est mise à disposition selon les termes de la Licence Creative Commons Attribution - Pas d'Utilisation Commerciale - Pas de Modification 4.0 International. 


\title{
Conversions in the kingdoms of Castile, Aragon and Valencia: A point of cohabitation
}

\author{
Nathan Robert Dodgens \\ Universidad de Alicante \\ nathanrobert.d@gmail.com
}

\begin{abstract}
Resumo:
Muito se tem escrito sobre a relação entra as comunidades minoritárias e o domínio cristão nos reinos hispânicos medievais. Contudo, a questão sobre a convivência social entre judeus e mudéjares tem sido objeto de um tratamento menos frequente, geralmente orientado para a ideia de uma relação caracterizada pelo conflito. $O$ presente texto pretende sublinhar a necessidade de um estudo mais aprofundado sobre esta questão, de modo a permitir uma visão mais clara do ambiente subjacente aos espaços partilhados por estes dois grupos.
\end{abstract}

Palavras-chave: Coabitação, mudéjares, judeus, conversões, Aragão, Castela, Valência

\begin{abstract}
:
Much has been written about the relationship between the minority communities of the medieval Spanish kingdoms and the ruling Christian community, however, how the Jews and Mudejars related to each other on a social level has not been so adequately developed. The work that has been done has been carried out with an assumption of bad blood between these two confessional minorities, and it is my intention to demonstrate that perhaps a deeper study is required to have a clearer understanding of what ambience dominated the spaces these two people groups shared.
\end{abstract}

Key Words: Cohabitation, Mudejars, Jews, conversions, Aragon, Castile, Valencia

\section{Introduction}

The presence of conversions among the confessional minorities of the late-medieval Iberian Peninsula, plays a vital part in the study of social relationships between the three religious people groups of the day, particularly, in this study, populations in the kingdoms of Castile, Aragon and Valencia covering cases anywhere between the $13^{\text {th }}$ and $15^{\text {th }}$ centuries. It is the purpose of this investigation to develop the idea that Mudejars and Jews cohabited in relative tolerance of each other's religions as demonstrated by the conversions of Jews to Islam and Muslims to Judaism. This occurrence seems to have been, if not widely-accepted, by no means infrequent. The geopolitical and chronological limits are admittedly a wide scope as this is a proposal for future investigation based on second hand references, which will then be limited to a more concise space and time.

Before continuing, it is of upmost importance to define the highly discussed notions of "cohabitation", "coexistence", "tolerance" and "integration", as well the connotation that will be ascribed to the adjective "peaceful". My use of these ideas will be akin to the ideas fleshed 
out by Maria Elena Diez Jorge who questions whether "peace" has been properly defined in relation to the presence of the three confessions in the medieval Iberian Peninsula, and urges a reconsideration of the exaggerated dimensions ascribed to "violence". To this she adds the necessity of recognizing that cohabitation implies coexistence at the very least in certain times and spaces of history, and that these cannot be properly defined without toleration, integration and negotiation ${ }^{1}$. It is my intention to include these same aspects in the cases here presented. I wish to make special emphasis on the word "cohabitation" as it is crucial to the theory expressed in this article. There are two meanings that could be given to this word in a historiographical sense, the first and most obvious being that of two people living together under the same roof. This much is not doubted to have happened, as King Alfonso $X$ himself was to record the fact that the three religions' devotees lived "bajo el mismo techo"2. Though this is an interesting aspect in my investigation, the other meaning is more relevant in how it relates to conversions between Judaism and Islam. H. Salvador Martínez expresses this cohabitation as "intersections" in the more general coexistence in which cross-religious relationships were established ${ }^{3}$. Here, the protagonists would not necessarily be living in the same house, however they would be in contact, whether as neighbors, business partners, clients, suppliers or perhaps, and this I add myself, as individuals truly interested in the religion of their fellow citizens. The following cases of conversions will be proposed as evidence of "intersections" in the coexistence, where relationships formed and the impact of these led even to a change of identity. Whether these changes were outward or inward is yet to be discovered, if it is even possible to discern the intentions of man in matters of faith.

As this paper is based on a theory that is in progression, it is necessary to introduce here the two opposing theories that are especially present in this article, and that deal with the topic of cohabitation. I have relied heavily on David Nirenberg and Jose Hinojosa Montalvo to formulate my theory, but it is by no means an exhaustive research that I have completed as of yet. Mr. Nirenberg presents his "communities of violence", creating a very convincing feeling that the general atmosphere between Jews and Mudejars was turbulent. In truth, he supports it with a long variety of documented cases, some of which I have mentioned in this paper. However, the tonic which Mr. Hinojosa introduces, of a more peaceful cohabitation, has caught my attention, for which reason my theory is based on ideas closely related to his. It is his belief that most of the violence that did indeed occur happened, not solely because of religious fervor, as has been considered to be the culprit by most historians, but also because of financial and or social reasons, making this more of a neighborly dispute typical of heterogeneous cohabitation. The cases that I have found have led me thus far precisely to this same conclusion. His viewpoint I have meted out below to serve as a basis for the posterior thoughts on inter-minority conversions.

It is an integral part of my research that theorizes that peaceful cohabitation among Jews and Mudejars was not surreal, nor even a distant possibility; instead, it was the actual general characteristic of their relationships. Although there are substantial records of discordant and even violent behavior among them, I propose that the disturbances were more a part of the peace than the antithesis of it. The following case develops this further.

\footnotetext{
${ }^{1}$ Maria Elena Diez Jorge, "Lecturas historiográficas sobre la convivencia y el multiculturalismo en el arte mudéjar", in Actas X Simposio Internacional de Mudejarismo: 30 años de Mudejarismo, memoria y futuro [1975-2005], Teruel, Centro de Estudios Mudéjares, 2007, p. 736,740.

${ }^{2}$ H. Salvador Martinez, La convivencia en la España del siglo XIII, Madrid, Ediciones Polifemo, 2006, p. 13.

${ }^{3}$ H. Salvador Martinez, La convivencia..., p. 14.
} 


\section{A case for violence within the general peace}

Anybody who has lived in a small town knows that seemingly insignificant things can cause rifts in the village, splitting the inhabitants into factions, leading to disputes, arguments, and sometimes riots. However, in the end, life continues and people in the village live in interaction, putting aside differences in favor of comfortable, safe living. In the town of Huesca, in the year 1392, the reality could not have been very different for the Jews, Muslims and Christians who shared life together there. Since time immemorial in Spanish towns, the festivales (public holidays), commemorations, funerals, weddings, victory marches, coronations, royal births - all were celebrated by processions in the cities' streets. Huesca was not the exception. However, with every procession and exequia real, or royal funeral rites, Jews and Mudejars disputed whose aljama would lead the parades.

The question that arises with this knowledge is perhaps why these two confessional groups would be interested in processions that exclusively commemorated Catholic kings and events. José Hinojosa Montalvo has an excellent theory that adds to the familiar picture of competitive neighbors, and as we will see later, is an echo of the idea of the late medieval lawyer, Oldradus de Ponte. As goes the popular theory, the Christian population was many times fed information to foment mistrust of the minority groups.

For this reason, Mudejars and Jews alike had plenty of motivation to be at least the dominant minority, holding some ideal of worth for the majority group. And so, in 1291, in Daroca, in the funeral procession meant to commemorate the death of King Alfonso, the Jews in the procession were attacked by armed Muslims as they passed though the Moorish quarters. Years later, in 1324, in Huesca, during the celebration of the victory of Prince Alfonso in Sardinia, twenty Jews were gravely injured by a Muslim attack as the procession passed through the Muslim neighborhood. For this attack, the Mudejar aljama was fined 50,000 sous of Jaca. It is assumed that the Muslims paid the fine; however, they insisted that it had been the Jews who had instigated the attack. Then in the year that the infante Francisco was born, while the Jews were celebrating with "saltos, baile y haciendo otras muchas expresiones de gozo", the Muslims once again attacked them. Two years before this last attack, the Jews and the Muslims had been arguing over who would preside in the funerary march in Fraga, commemorating Peter the Ceremonious' death. When it came time for the parade to start, the Jews were somehow able to advance to the head of the processions, resulting in a heated attack from the Muslims. For this last attack, the Muslims of Fraga were fined 1,000 gold florins ${ }^{4}$. Indeed it would seem that the intense rivalry between the minorities could only lead to a major separation to keep things from escalating. This did not happen, though processions continued to be a point of contention between them. Perhaps it was all of these incidents that provoked John I to initially decide, in 1392, that the Mudejars would always have preference in the processions in certain municipalities, among which was Huesca, given their willing incorporations into and services for the Christian armies ${ }^{5}$.

The Jews, on the other hand, did not render their services to the royal armies and were therefore, in that sense, politically inferior. However, after a few years, the privilege of preceding the processions was returned to the Jews, based on the argument of the antiquity of their religion ${ }^{6}$. Again, according to Hinojosa, there was an ideal valor at stake that neither side would give up. In Daroca and Fraga, it was the possibility of economic dominion, for which both sides would fight to obtain. This would trump the seemingly obvious although simplistic reasoning for

\footnotetext{
${ }^{4}$ David Nirenberg, Communities of Violence. Persecution of Minorities in the Middle Ages, Princeton, Princeton University Press, 1996, p. 180. All of these cases are discussed on page 180, by Nirenberg. It seems that these kinds of contentions were quite common.

${ }^{5}$ José Hinojosa Montalvo, Los Mudéjares: La Voz del Islam en la España Cristiana, Teruel, Centro de Estudios Mudéjares - Instituto de Estudios Turolenses, 2002, p. 152.

${ }^{6}$ D. Nirenberg, Communities of Violence..., p. 180.
} 
this violence that Jews and Mudejars simply did not get along. Another case that comes to my attention in 1327, in Seville, when, according to the Poema de Alfonso Onceno, Moors and Jews celebrated along with the Christians the arrival of the king. Such a festive scenario would be repeated, as Gonzalo Viñuales points out, in other local celebrations and parades, such as those during Easter and that of Corpus Christi ${ }^{7}$. The above cases could suggest a normal social relationship between the minorities that simply carried with it the baggage of rivalry when it came to "performing" before the majority authorities.

This concept proposed by José Hinojosa, that the violence many times observed between the two minorities was more the fruit of an ideological joust to become the preferred minority group of the government than of theological differences, inspired me to propose another phenomenon in judeo-muslim social relations - that of conversions - as one more indication that tolerance, yes, but also acceptance of each other, was evidence of peaceful cohabitation. Conversions between the two confessional minorities, would not necessarily have happened for the first seemingly logical reason, that of a religious conviction, but as a natural result of intersections in coexistence, actual inter-religious relationships that led to people adopting a new faith.

\section{The legal ramifications of converting}

When the legal consequences for converting are taken into consideration, it brings up the question as to why any member of a minority religion would dare to convert. The answer to this question is not the focus of this investigation, but it begs the question: "Was there so much animosity between Muslims and Jews as is typically believed"? The legislation, contrasted to the following cases, seems to indicate that there was a certain degree of affinity.

First it must be mentioned that the conversions that involved Christians confessing allegiance to Islam or Judaism were a serious matter. It had always been the popes' fear that old Christians and new alike were being exposed to contamination by the presence of Jews in the neighborhoods. But this point of view was not new. Recaredo had feared the "disidencia religiosa que tenia visos de transformarse en disidencia social y politica"8. In Guadalajara, when it became obvious that the presence of the Jews scattered throughout the Christian community brought a certain degree of danger of proselytism to the Christian population itself and, more importantly, of the judeo-conversos, the Jews were obligated to resettle in a newly created raval next to the Mudejar aljama ${ }^{9}$. The government believed to be effectively protecting their population from false religions. This would be the general practice in the Christian kingdoms of Castille and Aragon and Valencia, which according to my investigation only added to the ambience of cohabitation between Jews and Muslims.

The next aspect that must necessarily be dealt with is the possible difference between the legal boundaries of said kingdoms. I have taken Miguel Angel Ladero's comments in "Los mudéjares de Castilla cuarenta años después" on the legal situation in Castile as a general tonic of all three kingdoms dealt with in this article. He indicates that they do not seem to have changed much since his prior work, though he continues to defend the need of new cases, as is

\footnotetext{
${ }^{7}$ Gonzalo Viñuales Ferreiro, "Espacios de coexistencia entre moros y judíos en Castilla en la Edad Media: las fiestas", in Coexistence and cooperation in the middle ages, ed. Alessandro Musco and Giuliana Musotto, Palermo, Officina di Studi Medievali, 2014, p. 1543-1551.

8 Joseph Pérez, Historia de una tragedia: La Expulsión de los Judíos de España, Barcelona, Editorial Critica, 1993, p. 14.

9 Pablo Ortego Rico, "Los mudéjares castellanos: dinámica social y elementos culturales en la conformación de una identidad: siglos XI-comienzos del XVI", in Moriscos. Historia de una minoría, ed. Jesús Carrasco Vasquez, Madrid, Ayuntamiento de Guadarrama-Patronato Municipal de Cultura, 2009, p. 77.
} 
the purpose of this article ${ }^{10}$. Backtracking to his previous work he refers to, such as his paper from the $3^{\text {rd }}$ International Symposium of Mudejarismo, he states that there are differences within Castile as to how the laws were interpreted, and whether they were heeded or not, depending on if the mudejars were under realengo or under a lord's protection ${ }^{11}$. Much of the same would have been true in the kingdoms of Aragon, as Hinojosa sets the same variables to be considered in the Crown of Aragon, though his focus be specifically on the violence in the kingdom of Valencia ${ }^{12}$. The "situation" referred to was, again according to Ladero, that the "llibre de la xara e çuna" was the law that governed in cases of private rights, as well as traditional aspects of Muslim society, though of course these particular scenes of medieval life are difficult to capture given the lack of legal precedents recorded where minority authorities were concerned $^{13}$. For the Muslims, the law based on the Koran, prescribed death in many cases of infraction. As in practically every cultures' laws of the day, death was reserved for murderers, regardless of the religion of the victim. The Muslim murderer was to die, as prescribed in article 194 of the Sunna and Xara ${ }^{14}$. However, it was not only cases of murder that were punishable by death. The Muslim law also commanded that if a Muslim husband were to convert to another religion, the wife could no longer lie carnally with him, for it would be considered a sin. The matrimony in such a case would be null and void. However, if the law were transgressed, the law breakers were punishable by death ${ }^{15}$. The Koran also has much to say about the person who, having been a Muslim, submitted to the will of Allah, renounces his faith and claims another religion. This person would be worthy of death. The Jews on the other hand, though they did not have a specific law prescribing death for the infidel, did have traditions in their laws that sentenced death, for example to anyone who would practice idolatry, thus putting another god before the God of their fathers, Jehovah. With the cases that will be explored in the following paragraphs, we will see that the laws concerning mundane matters of society amongst the minorities in the Crown kingdom of Aragon and that of Valencia kept to the same guidelines as that of Castile.

\section{The Muslim Sunna and the Mosaic Law}

It is a known fact that the Christian authorities tended to leave the judicial matters of illegal sex, and other mundane matters between minorities, in the hands of the Muslim or Jewish authorities, whose punishment for said crimes was already established. In matters that involved Christians, it would stand to reason that they would document and execute punishment. However, in cases which involved only the two minorities, they would have no reason or desire to carry out judgments or records of such relations. In Girona, in 1321, the Jew, Chresches de Turri, and his family members, bought a license from Kings James I in order to be able to circumcise a Muslim boy, who had been the fruit of a relationship with a Muslim female slave. One of his ancestors, Abraham de Turri had also had a similar relationship with a Muslim slave. Around the same time as Chresches, in Huesca, another Jew was documented as having an affair with his Muslim slave and creating a problem by wanting to convert her, after she bore him a

\footnotetext{
${ }^{10}$ Miguel Ángel Ladero Quesada, "The Mudejars of Castile Forty Years Later", La España Medieval 33 (2010), p. 393.

11 Miguel Ángel Ladero Quesada, "Los Mudejares en los reinos de la corona de Castilla", in Actas III Simposio Internacional de Mudejarismo, Teruel, Instituto de Estudios Turolenses, 1986, p. 14-15.

12 José Hinojosa Montalvo, "Cristianos contra musulmanes: la situación de los mudéjares", in Conflictos sociales, políticos e intelectuales en la España de los siglos XIV y XV: XIV Semana de Estudios Medievales, ed. José Ignacio de la Iglesia Duarte, Nájera, Instituto de Estudios Riojanos, 2004, p. 349.

${ }^{13}$ M. Á. Ladero Quesada, "The Mudejars...", p. 395-396.

${ }^{14}$ Vicente García Edo e Vicent Pons Alós, Suna e Xara: La Ley de los Mudéjares Valencianos (Siglos XIII$X V)$, Castellón, Universidad Jaume I. Servicio de Comunicación y Publicaciones, 2009, p. 97.

${ }^{15}$ V. García Edo et V. Pons Alós, Suna e Xara..., p. 110.
} 
$\operatorname{son}^{16}$. In 1347, King Peter had established that the Muslims, under their law, the Sunna, would take care of administering justice in cases of adultery that did not include any Christian. This leaves us to understand that the two parties would have been Jewish and Muslim ${ }^{17}$. In order to obtain the Edict of 1347, the aljama of Valencia had to pay King Peter so that he would confirm their right to execute capital punishment of law-breakers ${ }^{18}$. It was not only King Peter the Ceremonious who had a hands-off policy when it came to minority issues; James I of Valencia also had had the same policy. All throughout the Furs de Valencia, the complex ethics behind the laws prohibiting cross cultural sex, demonstrates the seriousness of this crime in the eyes of the Catholic Church. However, the cases that present themselves hint at conviviality between both minority groups to the point where conversions came out of love affairs.

With this in mind, the decisions made by the three Christian kingdoms under consideration, were according to the edicts of the Council of Tarragona in 1235. Conversions between minorities should be punished by death. It was the initial policy to allow the Jewish and Moorish laws, to mete out justice among the minorities. Capital punishment was established for any member of either minority who would convert to a different religion, coinciding in this way with the legislation of the Jewish and Moorish laws. In 1315, the mayor of Lleida consulted King James II about a case of a Muslim who had converted to Judaism, reminding him of the laws that had been set in motion by James I. To this, the king simply responded that the mayor should follow the legislation if indeed it were still in effect. Why the mayor wished to be involved in matters that did not correspond to his jurisdiction is a matter of speculation, as it is not recorded, though would could imagine the desire of the local authorities to not lose the workforce and revenue this man represented. Nevertheless, with this answer, it can be supposed that the mayor followed through with the law by not intervening and allowed the qadi to take jurisdiction and sentence death to the person on trial. Peter the Ceremonious also ensured that his officials did not impede the qadi from executing judgment in a similar court hearing in $1338^{19}$. Nevertheless, similar to the relocation laws in the Mudejar capitulation treaties, what the rulings in specific cases actually were, was quite a different story.

It was not only Muslims who were sentenced to death, but Jews as well for transgressing the Mosaic law and converting to Islam. In a case documented by David Romano, and mentioned by Maria Teresa Ferrer i Mallol, Xátiva was the location of one such Jew who lost his life for changing his faith, due to the fervor of the Jewish community, which led them many times to seek death for unfaithful Jews ${ }^{20}$. David Nirenberg attributes this to the wealth that the former possessed, giving them more resources by which to pressure the Christian crown into conceding to them the right to execute those Jews who had be unfaithful to their religion ${ }^{21}$. In 1280 a document appears in Zaragoza which relates the verdict of three Jews who were transferred from the outskirts of the city, where they lived, to the city proper to receive their punishment. Their crime, having converted to Islam, was not viewed favorably by Jucef Ravaya, the treasurer of the king, who insisted on their prosecution ${ }^{22}$. It is supposed that, given the severity of the law with Jewish converts, and the political weight of Ravaya, the three convicts were met with the death penalty as punishment. Another reason to assume the worst outcome for these men is the case in 1284, only four years later, in which Maulet, a Jewish female convert was sentenced to death in Xátiva by the king himself ${ }^{23}$. Undoubtedly the death penalty was not incurred by all

\footnotetext{
${ }^{16}$ D. Nirenberg, Communities of Violence..., p. 184.

17 María Teresa Ferrer i Mallol, Els Sarrains de la Corona Catalano Aragonesa en el Segle XIV: Segregació $i$ Discriminació, Barcelona, CSIC, 1987, p. 270.

${ }^{18}$ D. Nirenberg, Communities of Violence..., p. 82-83.

19 M. T. Ferrer i Mallol, Els Sarrains..., p. 82-83.

${ }^{20}$ Idem, p. 82-83.

${ }^{21}$ Idem, p. 188.

22 Idem, p. 188-189.

${ }^{23}$ D. Nirenberg, Communities of Violence..., p. 188-189.
} 
Jewish converts to the Muslim faith, but there does seem to be a high rate of religious fervor in this aspect.

This being said, perhaps with the passage of time, the death penalty began to appear to be unnecessarily harsh for the local Christian authorities, for which reason they may have begun to contest the rulings of the minority authorities as we saw before in the case in Lleida in 1315. In the end, what did they care to what religion a person converted, if it was not to the Catholic faith? Didn't deaths of this manner serve to the detriment of the community? With time, the Muslims and Jews themselves seemed to be less inclined to condemn their own neighbors to death for their decision to pursue a different religion.

\section{More cases of conversions: Christian authorities involved}

As mentioned in the introduction, when it comes to the legal framework of the minority communities, blanket statements and conclusion can rarely be made, as the practice of the law varied depending on the kingdom, the local authorities and of course the time in which the cases are recorded. In some cases the Christian authorities took matters into their hands, whether because they were sought ought as mediators between minority factions, or because the aforementioned Council of Tarragona lost effectiveness and the sentences took on a lighter stance. The treatise, Jews and Sarracens in the Concilia of Oldradus, seems to have been either a stimulant in this change or at least a reflection of the thought process the Christian scholars were putting into the legislation. Oldradus de Ponte, the aforementioned Christian lawyer in the $14^{\text {th }}$ century, reflected on the question as to whether the authorities should even bother to judge and pass sentence on the minority conversos, specifically that of the Jew who would convert to Islam. His first argument was that there was no reason for the Christian court or church to fight for fidelity among two religions that were equally damned. Furthermore, deepening his reasoning, he proffers a definition for the concept of apostasy. Apostasy, according to Oldradus, is the leaving of a better doctrine for one that is inferior. Therefore, as Judaism was, in eyes of the Catholic Church, worse than Islam, converting to Islam from the Hebraic faith could not be considered apostasy. Did not the prayers of the faithful Christians on Good Friday include the pagan soul but exclude the Jew's? In the eyes of this medieval lawyer, this was surely a sign of greater damnation of the traitorous Jews. With all this in mind, then, the Jew ought not to be punished for converting to Islam. After all, as Oldradus sustained, the fight for conversions among minorities was simply a bid for more prestige before a Christian audience ${ }^{24}$. It was thanks to Oldradus that Jews converted to Islam now added a Christian authority to the defendant's bench to uphold their change in religion. However, Muslims converting to Judaism also found refuge in Oldradus' logic.

Nirenberg states the case of Maria, a young Muslim girl who had converted to Judaism, an act which caused a war of words between the Muslim community, backed by Catholic clergymen, and the Jewish community with a Christian lawyer in their service. The story tells that a Jewish man, Yuda, had taken an interest in the young girl, which some alleged was merely a sexual interest. He had then taken her to his house and had taught her the Hebrew religion, whereupon she was converted. In the fight over this girl's decision, the Jews also argued from the logic that Oldradus had used - if Islam was so much better, why was the great commission of the Bible to go to the Jews first and then to the gentiles (which would include the Muslims) ${ }^{25}$ ? They deferred to the scholarly arguments of this dominant authority to defend the fact that the conversions between minorities should not concern the Catholic Church. In 1335, the Jewish aljama of Lleida had complained that a Muslim had been locked up under the pretext that it had been heard of him that he wished to "adopt 'legem ebraycam'", the Hebrew law. The king

\footnotetext{
${ }^{24}$ Idem, p. 190-191.

25 Idem, p. 191-192.
} 
ordered him to be let go and that the converts no longer be persecuted in Lleida ${ }^{26}$. This order seemed to have little effect, for a number of years later, on the $12^{\text {th }}$ of August of 1356 , King Peter, by petition of the Jews of Lleida, ordered the liberation of Maria, with the royal declaration that her conversion to Judaism was not a crime ${ }^{27}$. In 1361, in Barcelona, persecution by inhabitants of the aljama of Barcelona was prohibited by King Peter. In this case, the Muslim, Lopello de Serrah Mahomet, a convert to Judaism and the Jewish community itself were enduring hostilities. The Jews, despite the favor conceded by the king, wished for Lopello, who had legally changed his name to Abraham, to undo the legal process, though not necessarily change his name back. The reason for this was that if the name were not legal, the aljama could avoid the litigation that could be a repercussion of his decision ${ }^{28}$. With royal decisions such as that of King Peter, it seemed that the minorities' religious freedom gained a somewhat appreciable ground.

The alternate route to condemning to death a convert was to demand the payment of a fine or to sentence the individual to corporal punishment without necessarily implying the taking of life. One of the earliest accounts of leniency with the matter of minority converts was in 1315 when James II writes the bayliff of Lleida, ordering him to "punish" Johannes, a Muslim woman who had converted to Judaism. This decision clearly ignores the clause of "perdida de person" or death from 1235, passed by the king's grandfather that had set said clause in motion, and of which the baile had used as pretext before the king to arrest the woman in the first place ${ }^{29}$. His efforts were of no avail, for the king seemed disposed, to conserve this woman's life. As mentioned before, perhaps it was the political or economic weight that the Jews had that spurred this decision forward. In 1356, Martín Ximénez of Tauste, a courtier of King John, was awarded full rights over the life of his Musim slave, María, and instead of losing her to capital punishment; he was able to demand a fine from her for having had sexual relationships with a Jew and then having become a Jew herself. She, in turn, having paid the "composició" was absolved of all her crimes and the consequences that these entailed ${ }^{30}$. In Alicante, in the kingdom of Valencia, in 1381, another court decision tells of the reduced punishment for conversion. Two Mudejar women decided to officially change their names from Fotoix and Axena to Jamila and Simfa, for the apparent reason that they had become Jews. Although María Teresa Ferrer i Mallol points out that it did not imply that there were no other punishments, the sole fine of 165 sous, which were payable to the general mayor of Valencia in Xixona, was recorded as the sentence ${ }^{31}$. Whatever the case may have been, death was certainly not one of the possibilities, for if such had been the case, the request to officially change their names would have been denied directly. In fact, the situation seems to imply more, as Nirenberg states that the question at hand was more of a matter of obtaining a license than of committing a crime ${ }^{32}$. The swing from capital punishment to the payment of a fine shows the variety of consequences that could be suffered for converting from one minority religion to another.

Taking into consideration the price of converting, it is amazing that so many Jews and Muslims thought it worthwhile to convert, keeping in mind that the documented cases are only a representation of all the other real life scenarios that never went through court. I would like to pose the question, then, as to whether these conversions were motivated by such deeply felt spiritual reasons. Were these conversions motivated by religious convictions or were there more practical reasons? Perhaps if a Jew or a Muslim believed that it would be easy enough to escape the attention that a conversion motivated by social reasons would bring, then they would take

\footnotetext{
${ }^{26}$ D. Nirenberg, Communities of Violence..., p. 188.

27 Idem, p. 185.

${ }^{28}$ Idem p. 188.

${ }^{29}$ Idem, p. 186-187.

${ }^{30}$ M. T. Ferrer i Mallol, Els Sarrains..., p. 82-83.

${ }^{31}$ Idem, p. 82-83.

${ }^{32}$ D. Nirenberg, Communities of Violence..., p. 188.
} 
the risk. If the numbers of recorded cases are any indication, then it would seem that many such converts defected unnoticed. In the name of bettering their social position, adapting to the culture, including religion, of their sentimental partner, or simply looking to fit in better in their masters' houses, it is likely that there were many undetected conversions. It would seem that we are talking about relational intersections resulting in a true indication of peaceful cohabitation.

As stated before, this theory, that has been exposed here, requires further work on several aspects in order to solidify the proposed ideas. This will be accomplished by creating a solid legal framework, which would include the general one, according to the kingdom, and the more customized laws, depending on the region, city or town. Also, a thorough search for additional cases will undoubtedly yield more information on the phenomenon of conversions between the minority groups, their reasons and their adherence to the laws in effect. Interminority conversions are one of many scenarios that would seem to indicate that peaceful cohabitation was a constant factor in the medieval Christian kingdoms. 